\title{
ЕФЕКТИВНІСТЬ УРАТОЗНИЖУВАЛЬНОЇ ТЕРАПІЇ ІЗ ЗАСТОСУВАННЯМ АЛОПУРИНОЛУ ТА ФЕБУКСОСТАТУ У ХВОРИХ НА ПОДАГРУ
}

\begin{abstract}
Резюме. Подагра $€$ найбільшим захворюванням суглобів із різним спектром клінічної маніфестації. Окрім рецидивного гострого артриту, підшкірних тофрусів і хронічного болю, вона значно впливає на рівень захворюваності та передчасної смертності як коморбідна патологія.

Мета дослідження - оцінити есрективність уратознижувальної терапії (УЗТ) із застосуванням алопуринолу та фребуксостату у хворих на подагру.

Матеріали і методи. У дослідженні взяли участь 110 хворих на подагру (100 \% чоловіків, середній вік - $(52,6 \pm 9,6)$ року). Серед обстежених 37 осіб із наявністю тофусів. 3 метою зниження сироваткового вмісту сечової кислоти (СК) хворі застосовували фебуксостат чи алопуринол. Ефективність лікування оцінювали через 24 тижні.

Результати досліджень та їх обговорення. Під впливом УЗТ відмічали позитивну динаміку клініко-лабораторних показників, однак у пацієнтів із наявністю тофусів вона була менш вираженою. У хворих, які використовували в якості УзТ фребуксостат, відмічали кращу динаміку таких показників, як частоту загострень подагричного артриту протягом останнього року, сироватковий рівень СК, активність захворювання за GAS, інтенсивність болю за ВАШ. А також вірогідність досягнути цільових рівнів СК у пацієнтів, які отримують феебуксостат, є утричі вищою (OR=3,52; 95\% ДІ 1,46; 8,45), ніж у пацієнтів, що застосовують алопуринол.

Висновки. Застосування фебуксостату для уратознижувальної терапії дозволяє швидше досягти цільових рівнів сечової кислоти та регресу артрологічного статусу.
\end{abstract}

Ключові слова: подагра; есрективність лікування; алопуринол; фребуксостат.

ВСтуп Подагра є найбільшим захворюванням суглобів із різним спектром клінічної маніфестації [1]. Окрім рецидивного гострого артриту, підшкірних тофусів і хронічного болю, вона значно впливає на рівень захворюваності та передчасної смертності як коморбідна патологія [2].

Згідно з рекомендаціями EULAR 2016 р. та ACR 2012 р., метою довготермінового лікування подагри $€$ досягнення цільового рівня сечової кислоти (СК) (нижче 300 або 360 мкмоль/л) для попередження загострень подагричного артриту та розчинення наявних депозитів сечокислого натрію [3-5]. Серед препаратів, які застосовують для уратознижувальної терапії (УЗТ), провідне місце займають інгібітори ксантиноксидази - алопуринол та фребуксостат. Однак незважаючи на чіткі вказівки щодо застосування УзТ, у багатьох випадках зазначають резистентність до сучаної фрармакотерапії та труднощі в досягненні цільового рівня СК [6]. Це може бути зумовлено патогенетичними чинниками, що впливають на розвиток і підтримання гіперурикемії та активного кристаліндукованого запалення.

Метою дослідження було оцінити ефективність УЗТ із застосуванням алопуринолу та феебуксостату у хворих на подагру.

МАТЕРІАЛИ I МЕТОДИ Дослідження проводили відповідно до принципів Гельсінської декларації і було схвалено Етичним комітетом Вінницького національного медичного університету імені М. І. Пирогова. Усі пацієнти дали згоду на участь у дослідженні. Діагноз подагри встановлювали на основі критеріїв ACR/E ULAR 2015 р. [7].

Проведено 24-тижневе відкрите контрольоване дослідження, в якому взяло участь 110 чоловіків, хворих на подагру. Це пацієнти, які не на момент дослідження не отримували уратознижувальної терапії. Вони отримували стандартне лікування відповідно до уніфрікованого клінічного протоколу надання медичної допомоги хворим на подагру. На період гострого подагричного артриту чи загострення хронічного подагричного артриту застосовували антиподагричну дієту та нестероїдні протизапальні препарати ("Моваліс" - 15 мг/добу, “Диклосренак" - 150 мг/добу або "Німесулід" - 200 мг/добу). У хворих із загостренням УЗТ розпочинали після купірування нападу. Стартова доза алопуринолу становила 100 мг/добу протягом 2 тижнів, і якщо за цей період не було досягнуто необхідного рівня СК, дозу титраційно збільшували кожні 2 тижні. Початкова доза фребуксостату була 40 мг, яку також титрували кожні 2 тижні для досягнення необхідної концентрації СК сироватки крові. Середньодобова доза алопуринолу становила 300 мг/добу, фебуксостату - 80 мг/добу.

У процесі спостереження оцінювали динаміку клінічних показників (кількість уражених суглобів, загострень подагричного артриту, рівень СК сироватки, інтенсивність болю за візуально-аналоговою шкалою (ВАШ)), фрункціональний стан за HAQ, активність захворювання за шкалою Gout Activity Score $\left(\mathrm{GAS}_{\text {step } 3 \text { c }}\right.$ ) [8].

Статистичну обробку матеріалу проводили із застосуванням універсальних статистичних програм MS Excel та Statistica SPSS22 for Windows. Для оцінки різниці між групами використовували параметричний t-критерій Стьюдента, а при непараметричному розподілі - критерій Манна-Уїтні та дисперсійний аналіз Краскела-Уолліса (Kruskal-Wallis). Для встановлення прогностичного значення УзТ визначали шансові відношення (OR, 95 \% Cl).

РЕЗУЛЬТАТИ ДОСЛІДЖЕНЬ ТА ЇХ ОБГОВОРЕННЯ Середній вік хворих становив $(52,6 \pm 9,6)$ року, середня тривалість захворювання - $(9,3 \pm 6,7)$ року. Кількість загострень протягом останнього року в середньому була

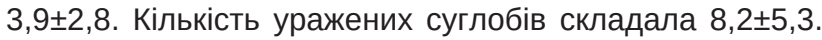
Підшкірні депозити сечової кислоти були виявлені у 37 хворих. Рівень СК в сироватці крові становив $(469,7 \pm 114,4)$ мкмоль/л. Інтенсивність болю за ВАШ виявилася $(54,6 \pm 24,4)$ см. Функціональна здатність за HAQ становила в середньому $0,8 \pm 0,6$.

Спочатку ми визначили ефективність терапії у хворих на подагру залежно від наявності тофрусів. У результаті проведеного дослідження було встановлено, що до лікування рівень СК у сироватці крові в групі хворих без то- 
фрусів у середньому становив $(452,3 \pm 106,8)$ мкмоль/л, разом з тим, як у хворих із хронічною тофрусною подагрою рівень СК до лікування був $(503,9 \pm 122,5)$ мкмоль/л (рис. 1). У процесі лікування спостерігали достовірне зменшення рівня урикемії на 24,4 \% у групі хворих без тофрусів та на 22,4% в групі хворих із наявністю тофрусів. Вміст СК після 24 тижнів лікування був на рівні $(341,7 \pm 72,2)$ мкмоль/л та $(390,9 \pm 87,6)$ мкмоль/л відповідно.

Аналізуючи динаміку вираженості болю за шкалою ВАШ, в обох групах хворих відмітили статистично достовірне зменшення інтенсивності больового синдрому (рис. 2). У пацієнтів із відсутністю тофусів інтенсивність болю через 6 місяців зменшилася $3(50,5 \pm 25,3)$ мм до $(28,6 \pm 19,9)$ мм, тоді як у хворих із хронічною тофууною подагрою - $3(62,6 \pm 20,7)$ мм до $(48,3 \pm 18,8)$ мм. Зауважимо, що динаміка вираженості больового синдрому в пацієнтів без тофрусів перевищувала таку в 1,5 раза порівняно $з$ хворими із наявністю тофрусів.

Результати оцінки функціональної здатності за HAQ також свідчать про його позитивну динаміку (рис. 3). На початку дослідження фрункціональна здатність за HAQ у хворих без тофусів становила 0,62 $\pm 0,60$, у пацієнтів із

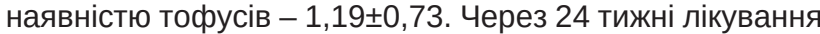
відмічали статистично достовірне зниження даного індексу в обох групах хворих. У пацієнтів без тофрусів показник фрункціональної здатності за опитувальником HAQ змен-

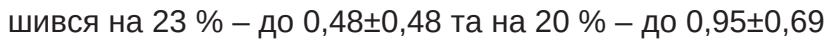
у хворих на хронічну тофрусну подагру.

Відмічали позитивну динаміку активності захворювання за шкалою GAS (рис. 4). Показник статистично

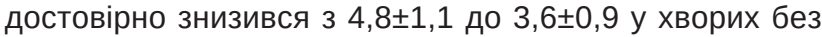
тофрусів та $37,9 \pm 1,5$ до $7 \pm 1,4$ у пацієнтів із хронічною тофрусною подагрою. Відсоток покращення шкали GAS у хворих без тофрусів виявився у 2,2 раза вищим порівняно 3 пацієнтами із наявністю тофусів і становив $25 \%$ та $11,4 \%$ відповідно.

Наступним фррагментом роботи була оцінка есрективності лікування залежно від виду УЗТ. Пацієнтів поділили на дві групи. До першої групи увійшло 78 (70,9 \%) хворих на подагру, що отримували алопуринол, до другої - 32 $(29,1$ \%) осіб, які в якості УЗТ приймали фребуксостат.

Клініко-демографрічну характеристику груп хворих залежно від виду УЗТ наведено в таблиці 1. Аналіз матеріалу свідчить про те, що до початку лікування між групами не відмічали статистично достовірних відмінностей.

Як свідчать результати, що наведені в таблиці 2, у хворих на подагру під впливом терапії через 24 тижні спостерігалась достовірна позитивна динаміка клініколабораторних даних. У групі пацієнтів, які застосовували фебуксостат, було більш виражене зниження показників, порівняно з групою хворих, які застосовували алопуринол. Так, через 24 тижні лікування пацієнти, які приймали

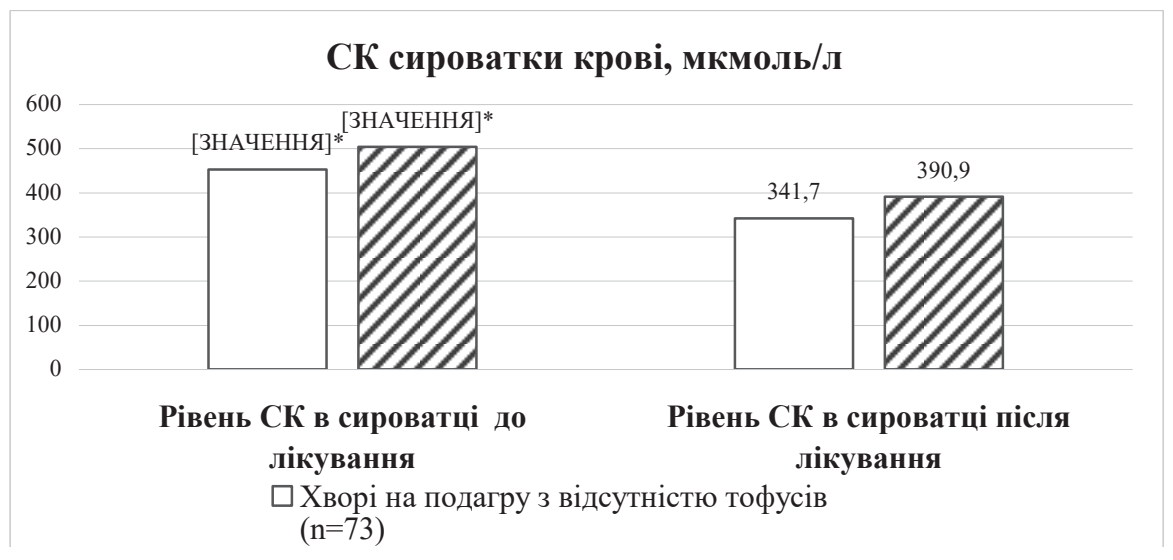

Рис. 1. Динаміка вмісту сечової кислоти у хворих на подагру залежно від наявності тофусів. Примітка. * - достовірні відмінності, порівняно з початковими рівнями, p<0,05.

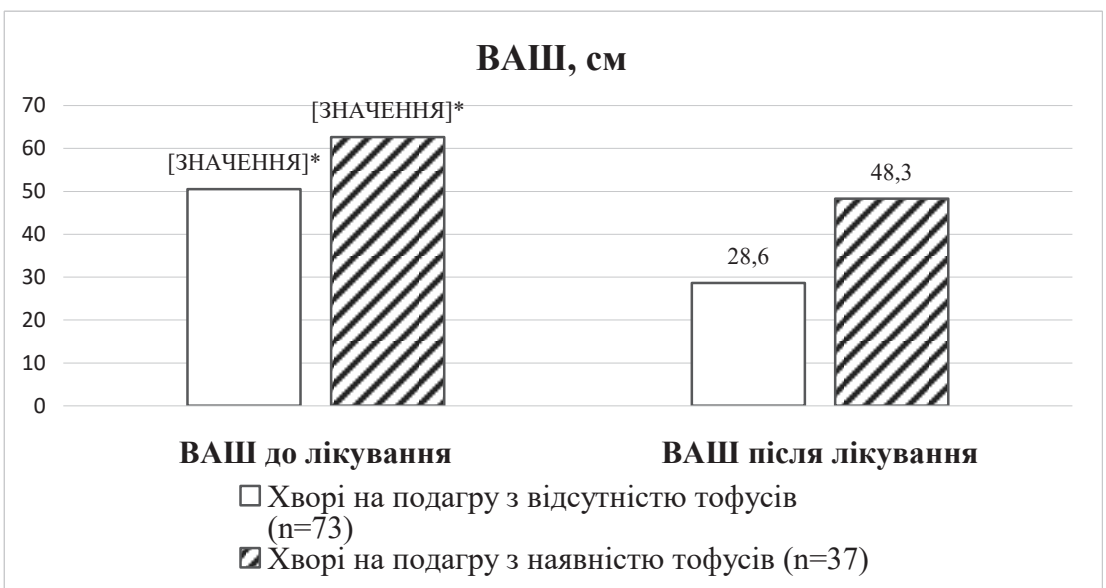

Рис. 2. Динаміка функціональної здатності за HAQ у хворих на подагру залежно від наявності тофусів. Примітка. * - достовірні відмінності, порівняно з початковими рівнями, $p<0,05$. 


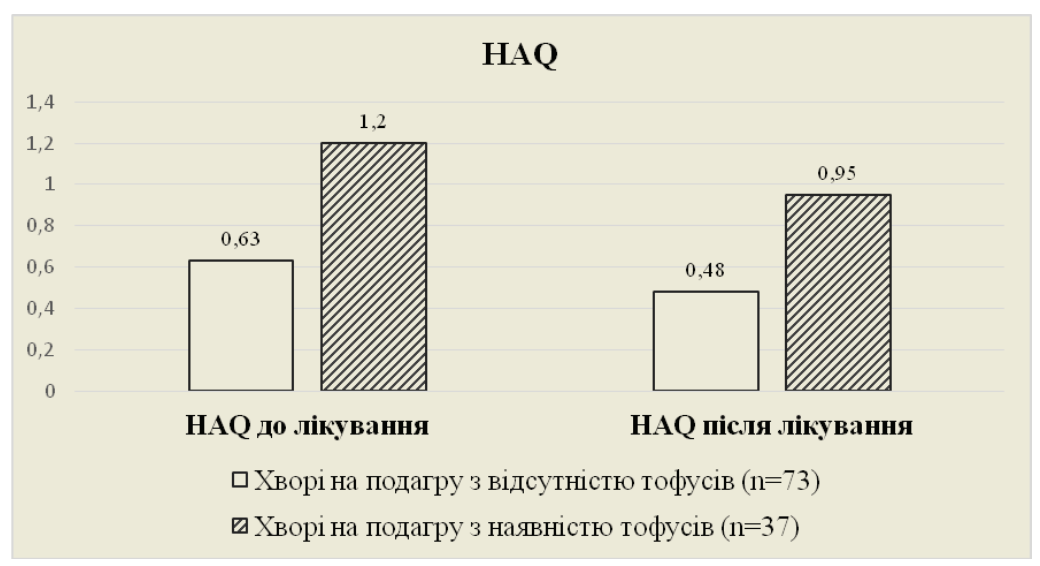

Рис. 3. Динаміка функціональної здатності за HAQ у хворих на подагру залежно від наявності тофусів. Примітка. * - достовірні відмінності, порівняно з початковими рівнями р<0,05.

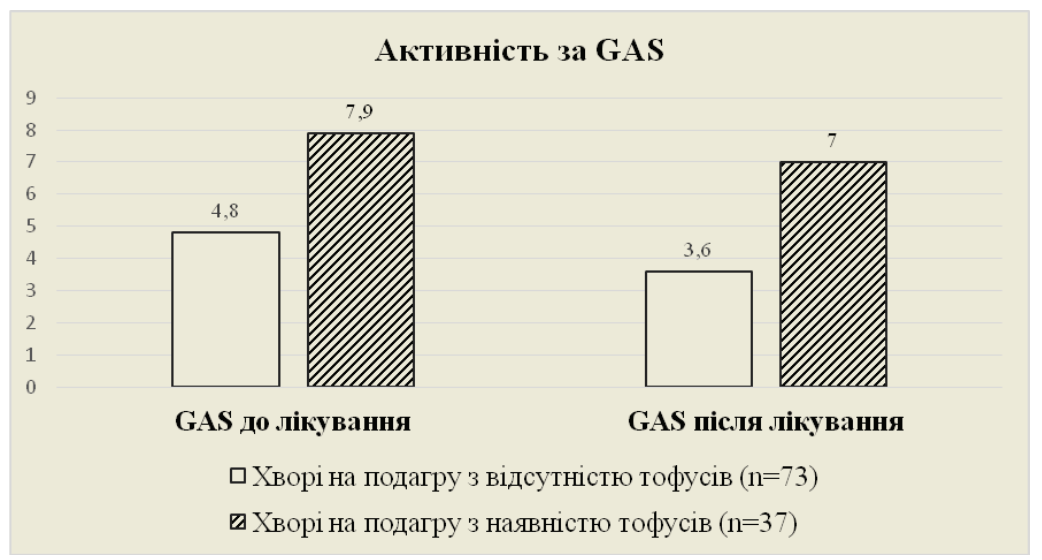

Рис. 4. Динаміка активності захворювання за GAS у хворих на подагру залежно від наявності тофусів. Примітка. * - достовірні відмінності, порівняно з початковими рівнями, $p<0,05$.

Таблиця 1. Клініко-демографічна характеристика груп хворих залежно від виду уратознижувальної терапії

\begin{tabular}{|c|c|c|c|}
\hline \multirow{2}{*}{\multicolumn{2}{|c|}{ Показник }} & \multicolumn{2}{|c|}{ Група хворих } \\
\hline & & хворі на подагру + алопуринол (n=78) & хворі на подагру + фребуксостат (n=32) \\
\hline Вік (роки) & $\mathrm{M} \pm$ & $53,2 \pm 9,7$ & \begin{tabular}{|r|}
$51,2 \pm 9,1$ \\
\end{tabular} \\
\hline Тривалість захворювання & $\mathrm{M} \pm$ & $9,7 \pm 6,6$ & $8,4 \pm 6,7$ \\
\hline Кількість нападів протягом останнього року & $\mathrm{M} \pm$ & $3,8 \pm 2,6$ & $4,1 \pm 3,2$ \\
\hline Кількість уражених суглобів & $\mathrm{M} \pm$ & $8,7 \pm 5,2$ & $6,9 \pm 5,4$ \\
\hline Наявність тофусів & $\mathrm{n}(\%)$ & $32(38)$ & $6(19)$ \\
\hline Кількість тофусів & $\mathrm{M} \pm$ & $5,9 \pm 13,2$ & $4,9 \pm 11,5$ \\
\hline $\begin{array}{l}\text { Рентгенологічна стадія } \\
\text { I } \\
\text { II } \\
\text { III }\end{array}$ & n (\%) & $\begin{array}{c}5(6,4) \\
39(50,0) \\
34(43,6)\end{array}$ & $\begin{array}{c}3(9,3) \\
19(59,4) \\
10(31,3)\end{array}$ \\
\hline 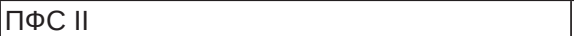 & $\mathrm{n}(\%)$ & $57(73,1)$ & $22(68,8)$ \\
\hline
\end{tabular}

сребуксостат, відмітили зниження частоти загострень на $36,6 \%$, тоді як в осіб, що отримували алопуринол, даний показник зменшився на 28,9\%. Кількість уражених суглобів знижувалась в обох групах майже однаково - на 20,7 $\%$ у хворих першої та на 20,3 \% в осіб другої груп. Окрім того, у групі хворих, які застосовували оребуксостат, інтенсивність больового синдрому зменшилась на 43,1%, тоді як в пацієнтів, які отримували алопуринол, - на 32,9 \%. У хворих під впливом лікування феебуксостатом вміст СК сироватки вірогідно знизився на $34,3 \%$, разом 3 тим, як у хворих першої групи в 1,9 раза менше - лише на 18,9 $\%(p<0,05)$. Оцінка динаміки інтегрального маркера активності за GAS засвідчила його достовірне зниження: на 26,2 \% у хворих, які приймали феебуксостат, та на 17,2 \% у групі осіб, які отримували алопуринол. Разом з тим, показник фрункціональної здатності за HAQ вірогідно зменшився на 28,6 та 12,5 \% відповідно.

Переносимість терапії була хорошою: лише у 3 хворих, які застосовували алопуринол, відмічали побічні дії - нудоту, діарею та тяжкість у правому підребер'ї. Ви- 
ISSN 1681-276Х. ВІСНИК НАУКОВИХ ДОСЛІДЖЕНЬ. 2018. № 3

Таблиця 2. Динаміка клініко-лабораторних маркерів у хворих на подагру залежно від виду уратознижувальної терапії $(\mathrm{M} \pm \sigma)$

\begin{tabular}{|c|c|c|c|}
\hline \multirow{2}{*}{\multicolumn{2}{|c|}{ Показник }} & \multicolumn{2}{|c|}{ Група хворих } \\
\hline & & $\begin{array}{c}\text { хворі на подагру + алопуринол }(\mathrm{n}=78) \\
1\end{array}$ & $\begin{array}{c}\text { хворі на подагру + фребуксостат }(\mathrm{n}=32) \\
2\end{array}$ \\
\hline \multirow{4}{*}{$\begin{array}{l}\text { Кількість нападів протягом } \\
\text { останнього року }\end{array}$} & & & \\
\hline & до включення & $3,8 \pm 2,6$ & $4,1 \pm 3,2$ \\
\hline & через 24 тижні & $2,7 \pm 2,3^{*}$ & $2,6 \pm 2,7^{*}$ \\
\hline & динаміка, \% & $-28,9 \pm 11,5$ & $-36,6 \pm 15,6$ \\
\hline \multirow[t]{3}{*}{ Кількість уражених суглобів } & до включення & $8,7 \pm 5,2$ & $6,9 \pm 5,4$ \\
\hline & через 24 тижні & $6,9 \pm 4,9$ & $5,5 \pm 5,2$ \\
\hline & динаміка, \% & $-20,7 \pm 5,8$ & $-20,3 \pm 3,7$ \\
\hline \multirow[t]{3}{*}{ СК у сироватці крові } & до включення & $455,7 \pm 108,3$ & $503,7 \pm 123,3$ \\
\hline & через 24 тижні & $369,4 \pm 80,1^{* \star}$ & $331,0 \pm 76,8^{\star \star}$ \\
\hline & динаміка, \% & $-18,9 \pm 26,0$ & $-34,3 \pm 37,7^{\#}$ \\
\hline \multirow[t]{3}{*}{ Активність за GAS } & до включення & $5,83 \pm 1,9$ & $6,1 \pm 1,9$ \\
\hline & через 24 тижні & $4,87 \pm 1,9^{*}$ & $4,55 \pm 2,1^{\text {** }}$ \\
\hline & динаміка, \% & $-17,2 \pm 0$ & $-26,2 \pm 0,1$ \\
\hline \multirow[t]{3}{*}{ ВАШ болю, мм } & до включення & $52,8 \pm 24,4$ & $58,9 \pm 24,3$ \\
\hline & через 24 тижні & $35,9 \pm 22,3^{\star *}$ & $33,5 \pm 20,2^{\star \star}$ \\
\hline & динаміка, \% & $-32,9 \pm 8,6$ & $-43,1 \pm 16,8$ \\
\hline \multirow[t]{3}{*}{ HAQ } & до включення & $0,8 \pm 0,7$ & $0,7 \pm 0,5$ \\
\hline & через 24 тижні & $0,7 \pm 0,6$ & $0,5 \pm 0,4$ \\
\hline & динаміка, \% & $-12,5 \pm 14,2$ & $-28,6 \pm 20$ \\
\hline
\end{tabular}

Примітки: 1) * - p<0,05 та p<0,01 відносно стану до включення;

2) \# - p<0,05 відносно динаміки показника в першій групі.

щеперераховані симптоми проходили самостійно без відміни чи додавання інших лікарських засобів.

Цільових рівнів СК у групі хворих, які отримували алопуринол, вдалося досягти у 38,5 \% випадків, тоді як серед осіб, що застосовували фебуксостат, частка хворих, що досягли цільового рівня СК, становила 68,7 \%.

Розрахунок шансових відношень засвідчив, що вірогідність досягнення цільових рівнів СК у пацієнтів, які застосовують фребуксостат, є втричі вищою, порівняно з хворими, що отримують алопуринол (OR=3,52; 95 \% ДІ 1,46; 8,45).

Таким чином, терапія забезпечувала регрес артрологічного статусу хворих, що підтверджується динамікою кількості уражених суглобів. Однак у когорті хворих, що

\section{СПИСОК ЛІТЕРАТУРИ}

1. Roddy E. Epidemiology of gout / E. Roddy, H. K. Choi // Rheumatic Disease Clinics. - 2014. - No. 40. - P. 155-175.

2. Comorbidities in patients with gout prior to and following diagnosis: case-control study / C. F. Kuo, M. J. Grainge, C. Mallen [et al.] // Annals of the Rheumatic Diseases. - 2016. - No. 75. - P. 210-217.

3. 2016 updated EULAR evidence-based recommendations for the management of gout / P. Richette, M. Doherty, E. Pascual [et al.] // Annals of the Rheumatic Diseases. - 2017. - Vol. 76 (1). - P. 29-42.

4. 2012 American College of Rheumatology guidelines for management of gout. Part 1: systematic nonpharmacologic and pharmacologic therapeutic approaches to hyperuricemia / D. Khanna, J. D. Fitzgerald, P. P. Khanna [et al.] // Arthritis Care \& Research. - 2013. - No. 64. - P. 1431-1446.

5. 2012 American College of Rheumatology guidelines for management of gout. Part 2: therapy and antiinflammatory prophylaxis використовували в якості УЗТ алопуринол, динаміка таких показників, як кількість загострень протягом останнього року, рівень урикемії, інтенсивність болю та функціональна здатність, була менш вираженою, порівняно з групою пацієнтів, що використовували фебуксостат, і загалом була меншою у 1,3-2,3 раза.

Наші результати $є$ подібними до таких, що отримані в інших дослідженнях при порівнянні ефективності різних схем УЗТ [9].

ВИСНОВКИ Фебуксостат у хворих на подагру є значно есрективнішим, ніж алопуринол, оскільки забезпечує швидший регрес артрологічного статусу та досягнення цільового рівня СК.

of acute gouty arthritis / D. Khanna, J. D. Fitzgerald, P. P. Khanna [et al.] // Arthritis Care \& Research. - 2013. - No. 64. - P. 1447-1461. 6. Gout, urate-lowering therapy, and uric acid levels among adults in the united states / S. P. Juraschek, L. C. Kovell, E. R. Miller, A. C. Gelber // Arthritis Care \& Research. - 2015. - No. 67. -P. 588-592.

7. 2015 Gout classification criteria: an American College of Rheumatology. European League Against Rheumatism collaborative initiative / T. Neogi, T. Jansen, N. Dalbeth [et al.] // Arthritis \& Rheumatology. - 2015. - No. 67. - P. 2557-2568.

8. Development and first validation of a disease activity score for gout / C. Scirè, G. Carrara, C. Viroli [et al.] // Arthritis Care \& Research. - 2016. - No. 68. - P. 1530-1537.

9. Cutolo M. Potency on lowering serum uric acid in gout patients: a pooled analysis of registrative studies comparing febuxostat vs. allopurinol / M. Cutolo, M. A. Cimmino, F. Perez-Ruiz // Eur. Rev. Med. Pharmacol. Sci. - 2017. - No. 21. - P. 4186-4195.

Отримано 03.08.18 
CI. V. Orlova, M. A. Stanislavchuk

M. Pyrohov Vinnytsia National Medical University

\section{TREATMENT EFFICACY OF URATE-LOWERING THERAPY WITH THE USE OF ALLOPURINOL AND FEBUXOSTAT IN PATIENTS WITH GOUT}

Summary. Gout is the largest joint disease with a different spectrum of clinical manifestation. In addition to recurrent acute arthritis, subcutaneous tophus and chronic pain, it has a significant effect on morbidity and premature mortality as comorbid pathology.

The aim of the study - to evaluate the effectiveness of urate-lowering therapy (ULT) with the use of allopurinol and febuxostat in patients with gout.

Materials and Methods. The study involved 110 patients with gout (100\% men, mean age $(52.6 \pm 9.6$ years). Among the surveyed 37 patients with the presence of tophi. In order to reduce serum uric acid (UA) patients used febuxostat or allopurinol. The effectiveness of the treatment was evaluated after 24 weeks.

Results and Discussion. Under the influence of ULT positive dynamics of clinical and laboratory parameters was noted, but in patients with tophi it was less pronounced. Patients using ULT febuxostat showed better dynamics of indicators such as the frequency of exacerbations of gouty arthritis during the last year, serum UA, activity by GAS, and the intensity of pain by VAS. Also, the probability of achieving the target UA levels in patients receiving febuxostat is three times higher $(\mathrm{OR}=3.52 ; 95 \% \mathrm{Cl} 1.46 ; 8.45)$ than in patients using allopurinol.

Conclusions. The use of febuxostat for urate-lowering therapy allows faster achievement of target levels of uric acid and regression of arthrological status.

Key words: gout; treatment efficacy; allopurinol; febuxostat.

СИ. В. Орлова, М. А. Станиславчук

Винницкий национальный медицинский университет имени М. И. Пирогова

\section{ЭФФЕКТИВНОСТЬ УРАТОПОНИЖАЮЩЕЙ ТЕРАПИИ С ИСПОЛЬЗОВАНИЕМ АЛЛОПУРИНОЛА И ФЕБУКСОСТАТА У БОЛЬНЫХ ПОДАГРОЙ}

Резюме. Подагра является крупнейшим заболеванием суставов с различным спектром клинической манифестации. Кроме рецидивирующего острого артрита, подкожных тофуссов и хронической боли, она оказывает значительное влияние на уровень заболеваемости и преждевременной смертности как коморбидная патология.

Цель исследования - оценить эффективность уратопонижающей терапии (УПТ) с применением аллопуринола и сребуксостата в больных подагрой.

Материалы и методы. В исследовании приняли участие 110 больных подагрой (100 \% мужчин, средний возраст - $(52,6 \pm 9,6)$ лет). Среди обследованных 37 больных с наличием тофусов. С целью снижения сывороточного содержания мочевой кислоты (МК) больные применяли феебуксостат или аллопуринол. Эффрективность лечения оценивали через 24 недели.

Результаты исследований и их обсуждение. Под влиянием УПТ отмечалась положительная динамика клинико-лабораторных показателей, однако у пациентов с наличием тофусов она была менее выраженной. У больных, которые использовали в качестве УПТ фебуксостат, отмечалась лучшая динамика таких показателей, как частота обострений подагрического артрита в течение последнего года, сывороточный уровень МК, активность заболевания по GAS, интенсивности боли по ВАШ. А также вероятность достичь целевых уровней МК у пациентов, получающих фребуксостат, оказалась втрое выше (OR=3,52; 95 \% ДИ 1,46; 8,45), чем у больных, которые получали алопуринол.

Выводы. Применение фебуксостата для уратопонижающей терапии позволяет быстрее достичь целевых уровней мочевой кислоты и регресса артрологического статуса.

Ключевые слова: подагра; эффрективность лечения; аллопуринол; фребуксостат. 